\title{
Penegakan Hukum Administrasi Terhadap Izin Usaha Industri Sebagai Instrumen YuridisPenaatan Lingkungan Hidup (Studi Tentang Pengawasan Dan Penerapan Sanksi Administrasidi Kota Semarang)
}

\author{
Moh. Hasyim
}

\begin{abstract}
Law enforcement in the form of control in the district Environmental Impact Assessment Agency which processes industrial permits in Semarang is still weak. This has occurred because the District Environmental Impact Assessment Agency's control is not implemented in an integrated or coordinated manner with other Associated Institutions. In terms of the object under control, basic issues like industrial permits and building permits have not been made the objects of control.
\end{abstract}

\section{Pendahuluan}

Pertumbuhan industri di banyak negara telah menimbulkan pencemaran dan perusakan lingkungan hidup, baik di darat, air maupun udara yang mengakibatkan timbulnya berbagai macam malapetaka lingkungan, seperti hujan asam, suhu bumi yang semakin panas akibat efek rumah kaca yang menimbulkan pemanasan global, berbagai macam penyakit dan lain-lain.'

Oleh karena itu, Undang-undang Nomor 23 Tahun 1997 tentang Pengelolaan

Lingkungan Hidup (disingkat UUPLH) yang diundangkan pada tanggal 19 September 1997 antara lain mengatur agar kegiatan perindustrian dan kegiatan pembangunan perekonomian pada umumnya jangan sampai mengorbankan pelestarian fungsi lingkungan hidup. Hal ini tercermin salah satunya dałam Pasal 18 ayat (1) yang menyatakan:

"Setiap usaha dan/atau kegiatan yang menimbulkan dampak besar dan penting terhadap lingkungan hidup wajib memiliki

'Absori, Penegakan Hukum Lingkungan dan Antisipasi dalam Era Perdagangan Bebas, (Muhammadiyah University Press, Surakarta, 2000), hlm. 7. 
analisis mengenai dampak lingkungan untuk memperoleh izin melakukan usaha dan/atau kegiatan".

Berkaitan dengan pembangunan industri, telah dikeluarkan UU Nomor 5 Tahun 1984 tentang Perindustrian berikut beberapa peraturan perundang-undangan pelaksanaannya. Dalam Pasal 13 ayat (1) Undang-undang No. 5 Tahun 1984 disebutkan bahwa setiap pendirian perusahaan industri maupun setiap perluasannya wajib memperoleh Izin Usaha Industri (selanjutnya disingkat IUI). Sesuai dengan ketentuan Pasal 18 ayat (1) UUPLH tersebut, pemberian IUI itu tentu saja harus dikaitkan dengan pelestarian fungsi lingkungan hidup. Dalam hal ini Pasal 21 ayat (1) UU No. 5 Tahun 1984 menentukan bahwa perusahaan industri wajib melaksanakan upaya keseimbangan dan kelestarian sumber daya alam serta pencegahan timbulnya kerusakan dan pencemaran terhadap lingkungan hidup akibat kegiatan industri yang dilakukannya. Apabila kewajiban ini dilanggar, maka diancam dengan pidana penjara selamalamanya 10 (sepuluh) tahun dan atau denda sebanyak-banyaknya Rp 100.000.000,(seratus juta rupiah) sebagaimana disebutkan dalam Pasal 27 UU No. 5 Tahun 1984.

Selain itu, terdapat juga pengaturan yang menyatakan bahwa perbuatan tersebut dapat dikenai sanksi administrasi antara lain berupa pencabutan izin usaha industri. Hal ini diatur dalam Pasal 10 PP No. 13 Tahun 1995 tentang Izin Usaha Industri.

Dalam UUPLH selain diatur sanksi perdata dan sanksi pidana, juga terdapat beberapa pasal yang mengatur sanksi administrasi, yaitu Pasal 25, 26 dan 27. Pasal 25 dan 26 mengatur paksaan pemerintahan, sedangkan Pasal 27 mengatur pencabutan izin usaha dan/atau kegiatan.

Agar kewajiban tersebut betul-betul dilaksanakan oleh perusahaan industri yang bersangkutan, dalam UUPLH terdapat beberapa pasal yang memberikan wewenang kepada pemerintah untuk secara preventif melakukan pengawasan, yaitu Pasal 22, 23 dan 24.

Persoalannya adalah, apakah dalam praktek berbagai ketentuan tersebut sudah dilaksanakan sebagaimana mestinya? Berdasarkan hasil pantauan Badan Pengelolaan Dampak Lingkungan (Bapedal), kualitas air sungai yang dikutip Bank Dunia menunjukkan bahwa 25-50 persen polutan yang mencemari sungai di Indonesia berasal dari industri. Persoalan lingkungan saat ini masih didominasi oleh sektor industri, baik yang berdiri sendiri maupun yang berlokasi $d i$ kawasan atau zona industri.?

Di Semarang misalnya, sebagai salah satu kota besar di Indonesia yang di dalamnya berdiri ribuan perusahaan industri pembuangan limbah dari berbagai industri di wilayah industri Genuk dan Tugu yang relatif dekat dengan pesisir dan laut telah mempengaruhi kualitas lingkungan di wilayah pesisir. Indikasi adanya pencemaran bisa dilihat dari menurunnya kualitas air di Kali Babon, Kali Sringin dan Kali Tenggang di wilayah Genuk. Pencemaran di Kali Babon bahkan menimpa tambak di wilayah Sayung. Demikian halnya, di wilayah Tugu, pencemaran di Sungai Karanganyar juga

\footnotetext{
${ }^{2}$ Kompas, 23 Maret 2001
} 
dikeluhkan penduduk. ${ }^{3}$ Di sisi lain, berbagai bencana seperti banjir, rob (banjir pasang) dan abrasi yang menyebabkan kerusakan tambak merupakan indikasi terjadinya penurunan daya dukung lingkungan di wilayah pesisir Semarang. ${ }^{4}$

Selain permasalahan tersebut, sejak diberlakukannya Undang-undang Nomor 22 Tahun 1999 tentang Pemerintahan Daerah (UUPD) 5 yang mencabut UU No. 5 Tahun 1974, timbul persoalan yang berkaitan dengan wewenang penerapan sanksi administrasi, terutama paksaan pemerintahan. Berdasarkan Pasal 25 UUPLH, wewenang menjatuhkan sanksi berupa paksaan pemerintahan ada pada Gubernur Kepala Daerah Tingkat I yang kemudian dapat dilimpahkan kepada Bupati Kepala Daerah Tingkat II dengan terlebih dahulu dikeluarkan Peraturan Daerah Tingkat I yang mengatur hal ini.

Masalahnya adalah bahwa pengaturan Otonomi Daerah dalam UUPD berbeda dengan pengaturan Otonomi Daerah dalam UU No. 5 Tahun 1974 yang menjadi acuan UUPLH. Berdasarkan Pasal 7 jo. 11 UUPD ${ }^{6}$ jelas bahwa Pemerintah Kabupaten atau Kota memiliki kewenangan di bidang lingkungan hidup. Dengan demikian, muncul permasalahan bahwa apakah dengan dimilikinya kewenangan ini secara otomatis Pemerintah
Kabupaten atau Kota sekaligus juga memiliki kewenangan untuk menjatuhkan sanksi administrasi yang menurut Pasal 25 UUPLH merupakan kewenangan Gubernur Kepala Daerah Tingkat I.

Uraian di atas mendorong penulis untuk menguraikan pengawasan dan penerapan sanksi administrasi terhadap perusahaan industri di Kota Semarang. Permasalahan yang diangkat dalam tulisan ini adalah: bagaimanakah penegakan hukum preventif dalam bentuk pengawasan yang dilakukan oleh pemerintah atas penaatan perusahaan industri yang memperoleh Izin Usaha Industri terhadap lingkungan hidup di Kota Semarang, apa implikasi berlakunya Undang-undang Nomor 22 Tahun 1999 tentang Pemerintahan Daerah terhadap kewenangan penerapan sanksi administrasi, dan bagaimanakah penerapan sanksi administrasi yang dilakukan oleh pemerintah terhadap pelanggaran atas kewajiban perusahaan industri yang memperoleh Izin Usaha Industri untuk melakukan upaya penaatan lingkungan hidup Kota Semarang.

Bahan yang dipergunakan dalam tulisan ini terdiri atas dua macam data, yaitu data sekunder dan data primer. Data sekunder diperoleh dari bahan kepustakaan, berupa bahan hukum primer, bahan hukum sekunder

${ }^{3}$ Sudharto P. Hadi, Dimensi Lingkungan Perencanaan Pembangunan, (Gadjah Mada University Press, Yogyakarta, 2001), hlm. 97.

4 bid, hlm. 94-95.

${ }^{5}$ Meskipun Undang-undang Nomor 22 Tahun 1999 telah dicabut dengan diberlakukannya Undangundang Nomor 32 Tahun 2004 tentang Pemerintahan Daerah, namun dernikian dalam UU yang baru ini pemerintahan daerah kabupaten daerah juga diberi otonomi daerah di bidang pengendalian lingkungan hidup yang berskala kabupaten/kota (Pasal Pasal 10 jo. Pasal 14). Dengan demikian, dalam hal ini tidak terdapat perbedaan yang mendasar antara UU No. 22 Tahun 1999 dengan UU No. 32 Tahun 2004.

${ }^{6}$ Sebagaimana dikemukakan di atas, dalam UU No. 32 Tahun 2004 hal ini diatur dalam Pasal 10 jo. Pasal 14. 
dan bahan hukum tertier dengan cara studi kepustakaan, sedangkan data primer diperoleh langsung dari lapangan dengan cara wawancara dengan beberapa narasumber tentang pengawasan dan penerapan sanksi administrasi terhadap perusahaan industri yang telah memperoleh izin usaha industri kaitannya dengan penaatan peraturan perundang-undangan di bidang lingkungan hidup yang dibatasi dalam kurun waktu 2 tahun (2001 dan 2002).

\section{Penegakan Hukum Lingkungan Administratif}

Siti Sundari Rangkuti menyatakan bahwa penegakan hukum lingkungan berkaitan erat dengan kemampuan aparatur dan kepatuhan warga warga masyarakat terhadap peraturan yang berlaku, yang meliputi tiga bidang hukum, yaitu administratif, pidana dan perdata. ${ }^{7}$ Menurut Mas Achmad Santosa, penegakan hukum administrasi di bidang lingkungan hidup memiliki beberapa manfaat strategis dibandingkan dengan perangkat penegakan hukum lainnya (perdata atau pidana) sebagai berikut:

1. Penegakan hukum administrasi di bidang lingkungan hidup dapat dioptimalkan sebagai perangkat pencegahan (preventive); Penegakan hukum administrasi (yang bersifat pencegahan) dapat lebih efisien dari sudut pembiayaan dibandingkan penegakan hukum pidana dan perdata.

2. Pembiayaan untuk penegakan hukum administrasi meliputi biaya pengawasan lapangan yang dilakukan secara rutin dan pengujian laboratorium, lebih murah dibandingkan dengan upaya pengumpulan bukti, investigasi lapangan, mempekerjakan saksi ahli untuk membuktikan aspek kausalitas (sebab akibat) dalam kasus pidana dan perdata;

3. Penegakan hukum administrasi lebih memiliki kemampuan mengundang partisipasi masyarakat. Partisipasi masyarakat dilakukan mulai dari proses perizinan, pemantauan penataan/ pengawasan, dan partisipasi dalam mengajukan keberatan dan meminta pejabat tata usaha negara untuk memberlakukan sanksi administrasi. $^{8}$

Lebih lanjut Mas Achmad Santosa menyatakan bahwa perangkat penegakan hukum administrasi dalam sebuah sistem hukum dan pemerintahan paling tidak harus meliputi lima perangkat yang merupakan prasyarat awal dari efektivitas penegakan hukum administrasi di bidang lingkungan hidup. Kelima perangkat itu ialah:

1. Izin, yang didayagunakan sebagai perangkat pengawasan dan pengendalian;

2. Persyaratan dalam izin dengan merujuk pada AMDAL, standar baku mutu lingkungan, peraturan perundangundangan;

3. Mekanisme pengawasan penaatan;

${ }^{7}$ Siti Sundari Rangkuti, Hukum Lingkungan dan Kebijaksanaan Lingkungan Nasional, (Airlangga University Press, Surabaya, Edisi Kedua, 2000), hlm. 208.

${ }^{8}$ Mas Achmad Santosa, Good Governance \& Hukum Lingkungan, (ICEL, Jakarta, 2001), hlm. 248. 


\section{Keberadaan pejabat pengawas (inspektur) yang memadai baik kuatitas maupun kualitasnya;}

5. Sanksi administratif. ${ }^{9}$

Dalam Notitie Handhaving Milieurecht 1981 di negeri Belanda, sebagaimana dikutip Koesnadi Hardjasoemantri, dikatakan bahwa penyidikan dan pelaksanaan sanksi administrasi atau sanksi pidana merupakan bagian akhir (sluitstuk) dari penegakan hukum. Yang perlu ada terlebih dahulu adalah penegakan preventif, yaitu pengawasan atas pelaksanaan peraturan. Pengawasan preventif ini ditujukan pada pemberian penerangan dan saran serta upaya meyakinkan seseorang dengan bijaksana agar beralih dari suasana pelanggaran ke tahap pemenuhan peraturan. ${ }^{10}$

Dengan mengacu pada pendapat tersebut, jelas bahwa penegakan hukum itu terdiri atas dua macam, yaitu:

1. Penegakan hukum preventif, yaitu penegakan hukum yang dilakukan dalam bentuk pengawasan dengan tujuan agar tidak terjadi pelanggaran, dan

2. Penegakan hukum represif, yaitu penegakan hukum yang dilakukan dalam bentuk penerapan sanksi, baik administrasi, pidana maupun perdata setelah terjadi suatu pelanggaran.
Pengawasan terhadap Penaatan

Perusahaan Industri Yang Telah - Memperoleh Izin Usaha Industri atas Lingkungan Hidup di Kota Semarang

Persoalan mendasar yang terlebih dahulu perlu memperoleh kejelasan adalah menyangkut siapa atau instansi apa yang berwenang melakukan pengawasan terhadap penaatan perusahaan industri yang telah memperoleh Izin Usaha Industri (IUI) untuk melaksanakan salah satu kewajibannya, yakni melakukan pencegahan pencemaran dan atau perusakan lingkungan hidup..

Di Kota Semarang, paling tidak terdapat 2 instansi pemerintahan yang memiliki kewenangan secara langsung melakukan pengawasan terhadap perusahaan industri setelah memperoleh IUI sebagai instrumen yuridis penaatan lignkungan hidup, yaitu Badan Pengendalian Dampak Lingkungan Daerah (Bapedalda) Kota Semarang yang pembentukannya diatur dalam Peraturan Daerah Kota Semarang Nomor 3 Tahun 2001 tentang Pembentukan, Organisasi dan Tata Kerja Lembaga Teknis Daerah Kota Semarang, dan Dinas Perindustrian dan Perdagangan yang pembentukannya diatur dalam Peraturan Daerah Kota Semarang Nomor 2 Tahun 2001 tentang Pembentukan Organisasi dan Tata Kerja Dinas Daerah Kota Semarang.

Dalam susunan organisasi Bapedalda Kota Semarang yang diatur dalam Pasal 5 Lampiran III Perda Kota Semarang No 3 Tahun 2001 terlihat ada 2 Bidang yang tampaknya

9 Mas Achmad Santosa, Pengembangan dan Penegakan Hukum Administrasi di Bidang Lingkungan Hidup dalam Konteks Otonomi Daerah, Makalah disampaikan dalam Environmental Law and Enforcement Training, Indonesia-Australia Specialised Training Project, di Semarang, 29 April-4 Mei 2002, hlm. 1.

${ }^{10}$ Koesnadi Hardjasoemantri, Hukum Tata Lingkungan,( Gadjah Mada University Press, Yogyakarta, Edisi Ketujuh, Cetakan Keempat Belas, 1999), hlm. 376. 
ada keterkaitan yang sangat erait antara keduanya, yaitu Bidang Pengawasan dan Pengendalian dan Bidang Pemantauan dan Pemulihan. Namun demikian, dalam Perda No. 3 Tahun 2001 tersebut maupun dalam lampirannya tidak dijelaskan perbedaan antara keduanya.

Menurut Suratno, SH, Kepala Bidang Pengawasan dan Pengendalian Bapedalda Kota Semarang, perbedaan antara keduanya adalah bahwa pengawasan dilakukan sebelum terjadi suatu masalah atau kasus, sedangkan pemantauan dilakukan setelah terjadi masalah atau kasus berdasarkan pengaduan dari masyarakat atau dilampauinya baku mutu lingkungan yang ditetapkan."1

Dari hasil' pengawasan dan pemantauan yang dilakukan Bapedaldan Kota Semarang terhadap perusahaan industri pada tahun $2001^{12}$ dapat diketahui bahwa perusahaan industri belum betul-betul secara optimal melaksanakan penaatan terhadap peraturan perundang-undangan lingkungan hidup sebagai upaya pengendalian pencemaran dan atau perusakan lingkungan hidup. Dengan lain perkataan, kesadaran masyarakat industri untuk melaksanakan pengelolaan lingkungan pada umumnya masih sangat rendah. Di antara 40 (empat puluh) perusahaan yang diawasi, yang menghasilkan limbah cair: 34 perusahaan, limbah padat: 36 perusahaan, dạn limbah gas/debu/kebisingan:
24 perusahaan. Hasil pengawasan tersebut juga menunjukkan bahwa sebagian besar perusahaan industri menghasilkan limbah dari kegiatan industri yang dilakukannya.

Dari hasil pengawasan tersebut juga diketahüi bahwa perusahaan industri yang memiliki instalasi pengolahan limbah (IPAL) dan masih dapat dioperasionalkan berjumlah 21 perusahaan, yang memiliki IPAL tetapi tidak berfungsi dengan baik berjumlah 4 perusahaan, sedangkan yang tidak memiliki IPAL berjumiah 15 perusahaan. Juga dapat diketahui bahwa perusahaan industri yang sudah melakukan pemantauan lingkungan berjumlah 27 perusahaan, sedangkan yang belum melakukan pemantauan lingkungan berjumlah 13 perusahaan. Data ini memperlihatkan masih banyaknya perusahaan industri yang belum melakukan penaatan lingkungan hidup dalam bentuk pelaksanaan kewajiban pengelolaan lingkungan hidup (hampir $50 \%$ ) dan pemantauan lingkungan hidup (lebih dari $30 \%$ ).

Secara umum kendala yang dihadapi oleh perusahaan dalam melaksanakan upaya pengelolaan dan pemantauan lingkungan adalah kurangnya sumber daya manusia yang bertanggung jawab atas kelangsungan pengelolaan-lingkungan baik sebagai operator IPAL maupun pengelolaan limbah padat gas, debu atau udara, di samping kurang efektifnya pelaksanaan pengawasan dan pemantauan oleh pemerintah maupun dinas

"Wawancara dengan Suratno, SH, Kepala Bidang Pengawasan dan Pengendalian Bapedalda Kota Semarang pada tanggal 29 April 2003.

${ }^{12}$ Berdasarkan data yang diperoleh dan diolah dari Laporan Kegiatan Proyek Pengawasan dan Pengendalian Pencemaran Lingkungan Bapedalda Kota Semarang Tahun 2001 dan Laporan Kegiatan Pemantauan Kasus Pencemaran Lingkungan, Bapedalda Kota Semarang, Tahun 2001, juga dari wawancara dengan beberapa nara sumber. 
atau instansi terkait, serta lemahnya penegakan hukum dalam bentuk penerapan sanksi.

Dilihat dari segi kuantitas, jumlah perusahaan industri yang diawasi sebanyak 40 perusahaan, sedangkan jumlah yang dipantau sebanyak 16 perusahaan. Dari 16 perusahaan yang dipantau ini, 6 di antaranya juga diawasi. Oleh karenanya, maka perusahaan industri yang diawasi dan dipantau pada tahun 2001 sebanyak 50 perusahaan. Jumlah ini terlampau kecil apabila dibandingkan dengan jumlah perusahaan industri yang ada di Kota Semarang, baik kecil, menengah maupun besar yang pada tahun 2001 berjumlah 1636 perusahaan. Jumlah ini yang termasuk kategori formal, sedangkan unit usaha yang non formal sampai dengan tahun 2000 berjumlah 2299 perusahaan industri ${ }^{13}$, sehingga jumlah total perusahaan industri baik formal maupun non formal adalah 3935 perusahaan.

Dengan demikian, apabila dibandingkan dengan jumlah perusahaan industri formal, maka jumlah perusahaan industri yang diawasi dan dipantau pada tahun 2001 di Kota Semarang hanya 3, $06 \%$ (50 dari 1636), sedangkan apabila dibandingkan dengan jumlah semua perusahaan industri yang ada baik formal maupun non formal, maka jumlah perusahaan industri yang diawasi lebih kecil lagi, yaitu $1,27 \%$ (50 dari 3935 ).

Sangat rendahnya jumlah perusahaan industri yang memperoleh pengawasan tersebut disebabkan antara lain oleh karena sedikitnya jumlah petugas pengawas, kurangnya sarana dan prasarana serta kecilnya anggaran. Saat ini, petugas pengawas yang ada pada Bapedalda Kota Semarang terdiri dari 5 orang dengan latar belakang pendidikan 2 orang sarjana geologi, 2 orang sarjana hukum dan 1 orang sarjana pemerintahan. Dalam menjalankan tugas pun mereka menggunakan kendaraan pribadi, karena memang tidak tersedia mobil dinas. ${ }^{14}$

Secara kualitatif, dapat diketahui bahwa pengawasan yang dilakukan hanya menekankan pada pelaksanaan pengelolaan dan pemantauan lingkungan sebagaimana telah dirumuskan dalam dokumen AMDAL atau UKL dan UPL atau SPPL. Persoalan mendasar seperti dimiliki tidaknya IUl serta dokumen-dokumen lain yang juga dipersyaratkan untuk memperoleh IUI seperti IMB ternyata luput dari pengawasan.

Salah satu faktor mendasar yang menyebabkan terjadinya hal itu yang dapat penulis peroleh adalah bahwa pengawasan yang dilakukan oleh Bapedalda tersebut tidak dilakukan secara terpadu dan terkoordinasi dengan instansi-instansi terkait seperti Dinas Perindustrian dan Perdagangan yang menerbitkan IUI dan Dinas Tata Kota dan Permukiman yang menerbitkan IMB dan ijin HO. Kedua Dinas ini serta instansi lain yang terkait baru dilibatkan dalam pelaksanaan pemantauan lingkungan, yakni ketika muncul masalah atau kasus. ${ }^{15}$

${ }^{13}$ Laporan Pelaksanaan Tugas Pokok dan Fungsi Tahun Anggaran 1999/2000, Kantor Departemen Perindustrian dan Perdagangan Kotamadya Semarang, hlm. 33.

${ }^{14}$ Wawancara dengan Bp. Suratno, SH, Kepala Bidang Pengawasan dan Pengendalian Bapedalda Kota Semarang pada tanggal 29 April 2003.

${ }^{15}$ Wawancara dengan Ibu Truli, Staf Bidang Pemantauan dan Pemulihan Bapedalda Kota Semarang pada tanggal 4 Nopember 2002. 
Hasil pengawasan dan pemantauan yang dilakukan oleh Bapedalda Kota Semarang pada tahun, 2002 tidak ada perbedaan yang signifikan dibandingkan dengan tahun 2001. Secara kuantitatif, jumlah perusahaan industri yang diawasi dan dipantau pada tahun $2002^{16}$ memang mengalami peningkatan dibandingkan dengan tahun sebelumnya, yaitu dari 50 menjadi 105 (60 dengan pengawasan dan 45 dengan pemantauan). Namun demikian, apabila dibandingkan dengan jumlah perusahaan industri yang ada peningkatan itu tidaklah banyak. Jumlah perusahaan yang diawasi dan dipantau sebanyak $6,2 \%$ (105 dari 1687). Selain itu, jumlah kasus lingkungan yang diadukan ke Bapedalda Kota Semarang juga meningkat tajam, yaitu dari 16 perusahaan pada tahun sebelumnya, menjadi 45 perusahaan. Dari 16 kasus yang dipantau pada tahun 2001, 10 di antaranya muncul kembali pada tahun 2002.

Sebagaimana dikemukakan di atas, selain Bapedalda, Dinas Perindustrian dan Perdagangan juga memiliki kewenangan untuk melakukan pengawasan terhadap perusahaan industri. Namun demikian, ternyata Dinas Perindustrian dan Perdagangan tidak melakukan pengawasan tersebut. Hal ini didasarkan baik pada dokumen tertulis ${ }^{17}$ yang sama sekali tidak menyebutkan adanya kegiatan pengawasan dimaksud, maupun pada wawancara yang penulis lakukan dengan beberapa responden yang menyatakan bahwa Dinas Perindag baru dilibatkan oleh Bapedalda dalam penanganan kasus, bukan pada pengawasan. ${ }^{18}$

Salah satu faktor yang menyebabkan hal itu adalah adanya persepsi di kalangan Dinas Perindag bahwa pengawasan itu merupakan kewenangan Bapedalda. ${ }^{19}$ Faktor penyebab lainnya yang sangat mendasar adalah bahwa dalam susunan organisasi Dinas Perindag yang diatur dalam Pasal 5 Lampiran VI Perda Kota Semarang No. 2 Tahun 2001 tidak ada bidang yang menangani pengawasan terhadap perusahaan industri dari aspek penaatan lingkungan hidup.
Implikasi Berlakunya UUPD terhadap Wewenang Pemerintah Kabupaten/Kota dalam Menerapkan Sanksi Administrasi terhadap Perusahaaan Industri Yang Tidak Melakukan Penaatan Lingkungan Hidup

${ }^{16}$ Berdasarkan data yang diperoleh dan diolah dari Laporan Kegiatan Proyek Peningkatan Kualitas Lingkungan, Sub Bidang Pengawasan.Pencemaran Lingkungan; Bidang Pengawasan dan Pengendalian, Bapedalda Kota Semarang, Tahun 2002 dan Laporan Kegiatan Penanganan Kasus Pencemaran Lingkungan, Bapedalda Kota Semarang, Tahun 2002, juga dari wawancara dengan beberapa nara sumber.

${ }^{17}$ Berupa Laporan Pelaksanaan Tugas Pokok dan Fungsi Tahun Anggaran 1999/2000, Kantor Departemen Perindustrian dan Perdagangan Kotamadya Semarang dan Laporan Akuntabilitas Kinerja Dinas Perindustrian dan Perdagangan Kota Semarang Tahun 2002

${ }^{18}$ Wawancara dengan Ibu Mugiarni, SH, Kasubdin Perindustrian Dinas Perindustrian dan Perdagangan Kota Semarang pada tanggal 11 Desember 2001, dengan Ibu Ir. Truli, Staf Bidang Pemantauan dan Pemulihan Bapedalda Kota Semarang pada tanggal 4 Nopember 2002 dan dengan Bp Susanto, Bagian Tata Usaha Dinas Perindag Kota Semarang pada tanggal 29 April 2003.

${ }^{19}$ Wawancara dengan Bp. Ir. Sabandi, Kasubdin Perindustrian Dinas Perindustrian dan Perdagangan Propinsi Jawa Tengah pada tanggal 30 April 2003. 
Implikasi berlakunya UUPD terhadap wewenang Pemerintah Daerah Kabupaten atau Kota dalam menerapkan sanksi administrasi bagi perusahaan industri yang melakukan pencemaran dan atau perusakan lingkungan hidup adalah sebagai berikut:

1. Paksaan pemerintahan yang berdasarkan Pasal 25 ayat (1) UUPLH merupakan wewenang Gubernur atau Kepala Daerah Tingkat I dan berdasarkan Pasal 25 ayat (2) UUPLH wewenang. itu dapat diserahkan kepada Bupati/Walikotamadya Kepala Daerah Tingkat II dengan Peraturan Daerah Tingkat 1, secara otomatis beralih menjadi wewenang Bupati/Walikota Kepala Daerah Kabupaten/ Kota tanpa diperiukan adanya Peraturan Daerah Propinsi yang mengatur hal ini, kecuali yang berkaitan dengan kewenangan Pemerintah Propinsi di bidang lingkungan hidup sebagaimana diatur dalam Pasal 3 ayat (5) angka 16 PP No. 25 Tahun 2000.

2. Berdasarkan Pasal 11 ayat (2), industri merupakan salah satu bidang yang dilaksanakan oleh Daerah Kabupaten dan Kota. Oleh karenanya, wewenang memberikan izin usaha industri sekaligus mencabutnya juga berada pada Daerah Kabupaten dan Kota yang menurut PP No. 8 Tahun 2003 tentang Pedoman Organisasi Perangkat Daerah, dilaksanakan oleh Dinas Kabupaten atau Kota, yang dalam hal ini adalah Dinas Perindustrian dan Perdagangan. Ini berbeda dengan pengaturan dalam Pasal 4 dan 5 Kep. Menperindag RI No. 589/MPP/Kep/10/ 1999 tentang Penetapan Jenis-jenis Industri dalam Pembinaan Masingmasing Direktorat Jenderal dan
Kewenangan Pemberian Izin Bidang Indsutri dan Perdagangan di Lingkungan Departemen Perindustrian dan Perdagangan yang menyatakan bahwa sesungguhnya wewenang untuk mengeluarkan izin di bidang perindustrian ada pada Menteri Perindustrian dan Perdagangan, akan tetapi, kemudian juga diatur adanya pelimpahan wewenang dari Menperindag kepada:

a. Sekretaris Jenderal Depperindag, untuk melakukan pemberian Izin Usaha Kawasan Industri dan Izin Perluasan Kawasan Industri,

b. Kepala Kantor Wilayah Depperindag, untuk melakukan pemberian IUI bagi jenis industri sebagaimana tercantum dalam Lampiran I Kep. Menperindag tersebut, yang nilai investasi perusahaan industri seluruhnya di atas Rp. 1.000.000.000,- (satu miliar rupiah) tidak termasuk tanah dan bangunan tempat usaha, dan kepada

c. Kepala Kantor Depperindag untuk melakukan pemberian TDI bagi jenis industri sebagaimana tercantum dalam Lampiran I Kep. Menperindag tersebut, yang nilai investasi perusahaan industri seluruhnya sampai dengan Rp. 200.000.000,(dua ratus juta rupiah) tidak termasuk tanah dan bangunan tempat usaha, dan untuk melakukan pemberian IUI bagi jenis industri sebagaimana tercantum dalam Lampiran I Kep. Menperindag tersebut, yang nilai investasi perusahaan industri seluruhnya di atas Rp. 200.000 .000 ,(dua ratus juta rupiah) sampai dengan Rp. 1.000.000.000,-(satu miliar rupiah) 
tidak termasuk tanah dan bangunan tempat usaha.

\section{Penerapan Sanksi Administrasi terhadap Perusahaan Industri Yang Telah Memperoleh Izin Usaha Industri Yang Tidak Melakukan Penaatan Lingkungan Hidup di Kota Semarang}

Di Kota Semarang, penulis tidak menemukan paling tidak dalam kurun waktu 5 tahun terakhir ini data tentang pemberian sanksi administrasi terhadap perusahaan industri yang kegiatan usahanya menimbulkan pencemaran dan atau perusakan lingkungan hidup. Yang dapat penulis peroleh adalah data tentang diterbitkannya surat yang diberikan oleh Kepala Bapedalda Kota Semarang kepada beberapa perusahaan industri yang berisi kewajiban yang harus dilakukan oleh perusahaan industri dan atau teguran atau peringatan. Surat Kepala Bapedalda tersebut diterbitkan setelah dilakukan pemantauan sebagai tindak lanjut dari permasalahan lingkungan (pencemaran dan atau perusakan lingkungan hidup) berdasarkan pengaduan dari masyarakat, pemberitaan di media massa dan dari sumber lainnya.

Pada tahun 2001 terdapat 4 perusahaan industri yang mendapat teguran, yaitu PT BBC, UD Bukit Timah, PT Surya Mas dan Jasa Timbal. ${ }^{20}$ Pada tahun 2002 terdapat 12 perusahaan industri yang memperoleh teguran/peringatan, bahkan 8 di antaranya merupakan peringatan terakhir, yaitu PT Fishindo, PT Kem farm, PT Sampharindo Perdana, PT Cerah Sampurna, PT Bukit Perak, PT Indo Sentra Pelangi, PT Karya Cipta Nyata Wisesa dan PT Indofood Sukses Makmur. ${ }^{21}$

Meskipun sanksi administrasi belum diberikan, setidak-tidaknya peringatan/teguran itu menurut Mas Achmad Santosa merupakan tahapan dari pemberian sanksi administrasi yang dengan demikian sudah dapat dikategorikan sebagai pelaksanaan penegakan hukum lingkungan administrasi. ${ }^{22}$

Hanya saja, perlu dipertanyakan, apakah pemberian peringatan itu sudah cukup memadai sehingga tidak diperlukan pemberian sanksi administrasi? Menurut hemat penulis, pemberian teguran itu saja belum cukup, akan tetapi perlu ditingkatkan menjadi sanksi administrasi, kalaupun tidak pencabutan izin, setidak-tidaknya dalam bentuk paksaan pemerintahan. Pendapat ini didasarkan antara lain . pada fakta tentang kasus pencemaran di Dukuh Tapak. Kasus ini berawal dari mulai dikembangkannya Dukuh Tapak pada dekade 1970-an sebagai kawasan industri yang kemudian pada tanggal 22 Nopember 1976 warga Dukuh Tapak mulai resah terhadap pencemaran yang melanda sawa dan tambak mereka. Sejak kasus itu diadukan oleh warga Dukuh Tapak melalui Lurah Zainal Arifin kepada Walikota Semarang

${ }^{20}$ Laporan Kegiatan Pemantauan Kasus Pencemaran Lingkungan, Bapedalda Kota Semarang, Tahun 2001. 2002.

${ }^{21}$ Laporan Kegiatan Penanganan Kasus Pencemaran Lingkungan, Bapedalda Kota Semarang, Tahun

${ }^{22}$ Mas Achmad Santosa, Pengembangan dan Penegakan Hukum Administrasi di Bidang Lingkungan Hidup dalam Konteks Otonomi Daerah, Makalah disampaikan dalam Environmental Law and Enforcement Training, Indonesia-Australia Specialised Training Project, di Semarang, 29 April-4 Mei 2002, hlm. 2. 
pada bulan Februari 1977, relatif baru dapat diselesaikan pada tahun 1992 sebagai antiklimaks dengan disepakatinya perdamaian di antara tripartit dengan model penyelesaian di luar pengadilan, setelah memakan waktu yang sangat panjang, yakni 16 tahun. ${ }^{23}$ Meskipun demikian, ternyata masalah Dukuh Tapak mencuat kembali pada tahun 2001. Kiranya persoalan pencemaran sungai Tapak memang merupakan salah satu indikator lemahnya penegakan hukum lingkungan di Indonesia.

Tidak diterapkannya sanksi administrasi sebagaimana diuraikan di atas disebabkan oleh beberapa faktor antara lain bahwa pemerintah lebih memprioritaskan pembinaan dan pengembangan kegiatan industri. ${ }^{24}$ Padahal, KTT Bumi tahun 1992 jelas mengamanatkan pembangunan berkelanjutan dengan menyerasikan pembangunan dengan lingkungan. Dengan demikian, terlihat bahwa komitmen pemerintah untuk melakukan penegakan hukum memang masih rendah.

Era otonomi daerah kiranya juga berbengaruh terhadap sikap pemerintah daerah yang lebih memprioritaskan untuk memngejar pendapatan asli daerah (PAD) yang sebesar-besarnya meskipun harus mengorbankan lingkungan, sehingga sanksi administrasipun tidak diterapkan. Sudharto P. Hadi menyatakan bahwa wacana dominan dari otonomi daerah yang diatur dalam UUPD didominasi oleh pemahaman tentang peningkatan PAD sehingga mendorong daerah untuk mengeksploitasi sebesarbesarnya sumber daya alam - tanpa memperhitungkan aspek kelestarian daya dukungnya. Otonmi daerah juga telah menimbulkan kekhawatiran munculnya pengelolaan lingkungan yang bersifat fragmentaris (terkotak-kotak) di antara Kabupaten dan Kota yang disebabkan oleh egoisme daerah yang cenderung akan mengorbankan lingkungan. ${ }^{25}$

Faktor penyebab lainnya adalah berbelitbelitnya sistem perizinan lingkungan di Indoesia sehingga mekanisme perizinan pun menjadi rumit dan tidak jelas. ${ }^{26}$

Secara komprehensif Mas Achmad Santosa menyatakan bahwa seluruh aspek penegakan hukum lingkungan di Indonesia sangatlah lemah, termasuk penegakan hukum administrasi, yang disebabkan beberapa faktor antara lain:27

1. Tidak adanya konsep, strategi dan program yang jelas dalam memberdayakan penegakan hukum lingkungan administrasi,

${ }^{23} \mathrm{M}$. Baiquni dan Susilawardani, Pembangunan Yang Tidak Berkelanjutan Refleksi Kritis Pembangunan Indonesia, (Transmedia Global Wacana, Yogyakarta, 2002), hlm. 100-113.

24 Disimpulkan dari wawancara dengan lbu Mugiami, SH, Kasubdin Perindustrian Dinas Perindustrian dan Perdagangan Kota Semarang pada tanggal 11 Desember 2001 dan dengan lbu Nur Weni, SH, Kepala Bidang Pemantauan dan Pemulihan Bapedalda Kota Semarang pada.tanggal 29 April 2003.

${ }_{25}$ Sudharto P. Hadi, Dimensi Lingkungan Perencanaan Pembangunan, (Gadjah Mada University Press, Yogyakarta, 2001), hlm. 89.

${ }^{26}$ Wawancara dengan Ibu Lilin Budiarti, SH, MM, Sekretaris Bapedalda Kota Semarang pada tanggal 11 Desember 2001.

${ }^{27}$ Mas Achmad Santosa, Pengembangan dan Penegakan Hukum Administrasi di Bidang Lingkungan Hidup dalam Konteks Otonomi Daerah, Makalah disampaikan dalam Environmental 
termasuk di dalamnya niat serta tekad untuk mendayakan izin sebagai alat pengendalian dampak lingkungan;

2. Ketiadaan konsep, strategi dan program tersebut jelas berpengaruh pada skala prioritas program;

3. Proses perizinan dilakukan secara tertutup antara regulator dengan penerima izin yang memudahkan terjadi penyelewengan mandat dan kewenangan oleh regulator;

4. Oleh karena tidak ada niat dan tekad untuk mendayagunakan izin sebagai alat pengendalian dampak lingkungan, maka izin yang ada pun pada umumnya tidak mencantumkan persyaratan-persayratan lingkungan yang bersifat operasional dan mudah dipahami;

5. Pemberian izin selama ini dipersepsikan sebagai sumber pendapatan para pejabat yang berurusan dengan izin, sehingga keputusan yang diambil tidak didasarkan pada pertimbangan-pertimbangan objektif, rasional, dan hukum yang berlaku.

Terkait dengan lemahnya penegakan hukum lingkungan dari aspek hukum administrasi tersebut, agar pemerintah sungguh-sungguh dalam menerapkan sanksi administrasi, secara yuridis masyarakat luas yang berkepentinganpun dapat melakukan "tekanan" dalam bentuk pengajuan permohonan kepada pejabat yang berwenang untuk menerapkan sanksi administrasi. Hal ini diatur dalam Pasal 25 ayat (3) dan Pasal 27 ayat (3) UUPLH.

Hanya saja, permohonan tersebut tidak dapat berfungsi dengan baik apabila tidak mendapat respons dari pejabat yang berwenang untuk menindaklanjuti permohonan itu. Dalam hal demikian, meskipun tidak diatur dalam UUPLH, menurut hemat penulis, apabila pemerintah dengan sengaja atau lalai tidak menerapkan sanksi administrasi sehingga menimbulkan kerugian pada pihak ketiga yang berkepentingan (masyarakat), maka pihak ketiga tersebut dapat menggugat pejabat pemerintah itu atas dasar onrechtmatige overheidsdaad (perbuatan melawan hukum yang dilakukan oleh pemerintah). Pengertian "hukum" dalam "perbuatan melawan hukum oleh pemerintah" itu selain mencakup hukum tertulis juga meliputi hukum tidak tertulis, ${ }^{28}$ yang kedua-duanya harus menjadi dasar untuk menerapkan atau tidak menerapkan sanksi administrasi.

Dalam kondisi lemahnya penegakan hukum lingkungan sebagaimana digambarkan di atas, Otto Soemarwoto menawarkan konsep Atur Diri Sendiri (ADS) sebagai instrumen pengelolaan lingkungan hidup selain instrumen yuridis (Atur dan Awasi), instrumen ekonomi dan instrumen suasif. Instrumen ADS dilakukan dengan cara mengubah pandangan dunia bisnis bahwa lingkungan hidup sebagai faktor eksternal bisnis menjadi faktor internal bisnis. ${ }^{29}$

Law and Enforcement Training, Indonesia-Australia Specialised Training Project, di Semarang, 29 Apri-4 Mei 2002, hlm. 3.

${ }^{28}$ Soerjono, Perbuatan Melawan Hukum Yang Dilakukan Oleh Penguasa/O.O.D dan Masalah Ganti Rugi, dalam Proyek Peningkatan Tertib Hukum dan Pembinaan Hukum Mahkamah Agung, Himpunan Karangan di Bidang Hukum Tata Usaha Negara, Jakarta, 1993, hlm. 47. 


\section{Simpulan}

Dari uraian di atas, dapat ditarik kesimpulan sebagai berikut:

1. Penegakan hukum preventif dalam bentuk pengawasan oleh Bapedaida Kota Semarang terhadap perusahaan industri yang memperoleh Izin Usaha Industri (IUI) untuk melakukan penaatan lingkungan hidup di Kota Semarang pada tahun 2001 dilakukan hanya terhadap 50 perusahaan industri $(3,6 \%)$, sedangkan pada tahun 2002 mengalami sedikit peningkatan sehingga menjadi 105 perusahaan $(6,2$ $\%)$. Sangat rendahnya jumlah perusahaan industri yang diawasi itu disebabkan oleh beberapa faktor seperti: sedikitnya jumlah petugas pengawas (hanya 5 orang) serta keterbatasan sarana, prasarana dan dana. Selain itu juga karena instansi lain yang terkait tidak melakukan pengawasan, yaitu Dinas Perindustrian. Dari segi objek yang diawasi, pengawasan yang dilakukan Bapedalda hanya terfokus pada pengelolaan dan pemantauan lingkungan yang dilakukan perusahaan industri, sedangkan hal-hal pokok lainnya seperti dimiliki tidaknya IUI dan IMB tidak menjadi objek pengawasan. Hal ini karena pengawasan yang dilakukan Bapedalda tersébut tidak dilakukan secara terpadu dan terkoordinasi dengan instansi lain yang terkait.

2. Secara implisit, berlakukanya Undangundang Nomor 22 Tahun 1999 tentang Pemerintahan Daerah membawa implikasi bahwa Bupati/Walikota memiliki wewenang menerapkan sanksi administrasi berupa paksaan pemerintahan tanpa terlebih memperoleh delegasi wewenang dari Gubernur yang dituangkan dalam Peraturan Daerah Tingkat I.

3. Penerapan sanksi administrasi terhadap perusahaan industri yang melakukan pelanggaran atas kewajiban untuk melakukan upaya penaatan lingkungan hidup di Kota Semarang belum pernah dilaksanakan baik oleh Walikota yang memiliki kewenangan menerapkan sanksi administrasi berupa paksaan pemerintahan, maupun oleh Kepala Dinas Perindustrian dan. Perdagangan yang memiliki kewenangan menerapkan sanksi administrasi berupa pencabutan izin usaha industri. Sanksi yang ada adalah pemberian kewajiban dan/atau peringatan/teguran oleh Kepala Bapedalda Kota Semarang yang ditujukan kepada perusahaan industri yang tidak melakukan penaatan lingkungan. Lemahnya penegakan hukum administrasi ini disebabkan oleh beberapa faktor antara lain berupa: belum kuatnya komitmen seluruh instansi pemerintahan untuk menyelaraskan pembangunan dan lingkungan hidup sehingga lebih memprioritaskan pembinaan dan pengembangan dunia industri daripada perlindungan lingkungan hidup, pemahaman yang salah bahwa otonomi daerah berarti mengejar PAD sebesarbesarnya meskipun harus dengan mengorbankan lingkungan, berbelit-belitnya sistem perizinan lingkungan di Indonesia sehingga mekanisme perizinan menjadi rumit dan tidak jelas yang padà akhimya juga

${ }^{29}$ Otto Soemarwoto, Atur Diri Sendiri Paradigma Baru Pengelolaan Lingkungan Hidup, (Gadjah Mada University Press, Yogyakarta, 2001), hlm. 92-124. 
berpengaruh pada penegakan hukum, dan tidak adanya konsep, strategi dan program yang jelas dalam memberdayakan penegakan hukum lingkungan administrasi.

\section{Saran}

Mengacu pada beberapa kesimpulan tersebut, kiranya perlu dikemukakan beberapa saran sebagai berikut:

1. Agar pelaksanaan pengawasan terhadap perusahaan industri dari aspek penaatan lingkungan hidup di Kota Semarang menjadi lebih baik, kuantitas maupun kualitasnya, kiranya perlu dilakukan: perubahan susunan organisasi Dinas Perindustrian dan Perdagangan Kota Semarang sehingga ada bidang yang menenangani pengawasan terhadap perusahaan industri.dari aspek penaatan lingkungan hidup, penambahan jumlah petugas pengawas sesuai dengan kualifikasi yang ditentukan, peningkatan sarana, prasarana dan dana, dan keterpaduan dan koordinasi dengan seluruh instansi terkait dalam melakukan pengawasan.

2. Dengan berlakunya Undang-undang Nomor 22 Tahun 1999 tentang - Pemerintahan Daerah perlu dilakukan perubahan terhadap Undang-undang Nomor 23 Tahun 1997 tentang Pengelolaan Lingkungan Hidup (UUPLH) dalam rangka penyesuaian terhadap Undang-undang Nomor 22 Tahun 1999 tersebut yang memuat pengaturan tentang

- otonomi daerah yang berbeda dengan pengaturan dalam Undang-undang Nomor 5 Tahun 1974 sebagai dasar bagi UUPLH dalam mengatur pengelolaan lingkungan di daerah. Dalam perubahan UUPLH tersebut, dalam kaitannya dengan penerapan sanksi administrasi kiranya perlu disebutkan bahwa paksaan pemerintahan merupakan wewenang Bupati atau Walikota.

3. Agar penerapan sanksi adminsitrasi terhadap perusahaan industri yang tidak melaksananakan penaatan lingkungan hidup di Kota Semarang menjadi lebih kuat, perlu ditingkatkan komitmen dari pemerintah menyelaraskan pembangunan dengan lingkungan hidup, kualitas para aparat penegak hukum sehingga mereka memiliki tekad yang kuat untuk melakukan penegakan hukum. Di samping itu juga perlu dilakukan penyederhanaan sistem perizinan lingkungan yang menghasilkan mekanisme perizinan yang jelas. Masyarakat (pihak ketiga yang berkepentingan) juga perlu meningkatkan upaya dalam bentuk pengajuan permohonan kepada pejabat yang berwenang untuk menerapkan sanksi administrasi.

\section{Daftar Pustaka}

Absori, 2000, Penegakan Hukum Lingkungan dan Antisipasi dalam Era Perdagangan Bebas, Muhammadiyah University Press, Surakarta.

Hardjasoemantri,Koesnadi, 1999, Hukum Tata Lingkungan, Edisi Ketujuh, Cetakan Keempat Belas, Gadjah Mada University Press, Yogyakarta.

Santosa,Mas Achmad, 2001, Good Governance \& Hukum Lingkungan, ICEL, Jakarta. 
, Pengembangan dan Penegakan Hukum Administrasi di Bidang Lingkungan Hidup dalam Konteks Otonomi Daerah, Makalah disampaikan dalam Environmental Law and Enforcement Training, IndonesiaAustralia Specialised Training Project, di Semarang, 29 April-4 Mei 2002.

M. Baiquni dan Susilawardani, 2002, Pembangunan Yang Tidak Berkelanjutan Refleksi Kritis Pembangunan Indonesia, Transmedia Global Wacana, Yogyakarta.

Soemarwoto, Otto, 2001, Atur Diri Sendiri Paradigma Baru Pengelolaan Lingkungan Hidup, Gadjah Mada University Press, Yogyakarta.

Proyek Peningkatan Tertib Hukum dan Pembinaan Hukum Mahkamah Agung, 1993, Himpunan Karangan di Bidang Hukum Tata Usaha Negara, Jakarta.

Rangkuti Siti Sundari 2000, Hukum Lingkungan dan Kebijaksanaan Lingkungan Nasional, Airlangga University Press, Surabaya.

Hadi, Sudharto P., 2001, Dimensi Lingkungan Perencanaan Pembangunan, Gadjah Mada University Press, Yogyakarta.

UU No. 23 Tahun 1997 tentang Pengelolaan Lingkungan Hidup.

UU No. 5 Tahun 1984 tentang Perindustrian.

UU No. 22 Tahun 1999 tentang Pemerintahan Daerah.

UU No. 32 Tahun 2004 tentang Pemerintahan Daerah.
PP No. 25 Tahun 2000 tentang Kewenangan Pemerintah dan Kewenangan Propinsi Sebagai Daerah Otonom.

PP Nomor 8 Tahun 2003 tentang Pedoman Organisasi Perangkat Daerah.

PP. No. 13 Tahun 1995 tentang Izin. Usaha Industri.

Keputusan Menteri Perindustrian dan Perdagangan No. 589/MPP/Kep/10/ 1999 tentang Penetapan Jenis-jenis Industri dalam Pembinaan Masingmasing Direktorat Jenderal dan Kewenangan- Pemberian Izin Bidang Indsutri dan Perdagangan di Lingkungan Departemen Perindustrian dan Perdagangan.

Perda Kota Semarang Nomor 2 Tahun 2001 tentang Pembentukan Organisasi dan Tata Kerja Dinas Daerah Kota Semarang.

Perda Kota Semarang Nomor 3 Tahun 2001 tentang Pembentukan, Organisasi dan Tata Kerja Lembaga Teknis Daerah Kota Semarang.

Laporan Kegiatan Proyek Pengawasan dan Pengendalian . Pencemaran Lingkungan Bapedalda Kota Semarang Tahun 2001.

Laporan Kegiatan Pemantauan Kasus Pencemaran Lingkungan; Bapedalda Kota Semarang, Tahun 2001.

Laporan Kegiatan Proyek Peningkatan - Kualitas Lingkungan, Sub Bidang Pengawasan

Pencemaran Lingkungan, Bidang Pengawasan dan Pengendalian, Bapedalda Kota 
Semarang, Tahun 2002.

Laporan Kegiatan Penanganan Kasus

Pencemaran Lingkungan, Bapedalda Kota Semarang, Tahun 2002.

Laporan Pelaksanaan Tugas Pokok dan

Fungsi Tahun Anggaran 1999/2000, Kantor Departemen Perindustrian dan
Perdagangan Kotamadya Semarang.

Laporan Akuntabilitas Kinerja Dinas

Perindustrian dan Perdagangan Kota Semarang Tahun 2002, Dinas Perindustrian dan Perdagangan Kota Semarang.

Kompas, tanggal 23 Maret 2001.

$$
\pi
$$

